\title{
Practices and Beliefs Relating to Authentic Assessment of Kindergarten Teachers in the Suburbs of Jerusalem
}

\author{
Ramzi F. Haroun ${ }^{1} \&$ Buad M. Alkhales ${ }^{2}$ \\ ${ }^{1}$ Dept. of Curriculum and Instruction, Faculty of Educational Sciences, the University of Jordan, Amman, Jordan \\ ${ }^{2}$ Dept. of Elementary and Kindergarten Education, Faculty of Educational Sciences, Al-Quds University, \\ Jerusalem, Palestine \\ Correspondence: Ramzi F. Haroun, Dept. of Curriculum and Instruction, Faculty of Educational Sciences The \\ University of Jordan, Amman, Jordan. E-mail: haroun@ju.edu.jo \\ Received: December 27, 2018 \\ Accepted: January 8, 2019 \\ Online Published: February 25, 2019 \\ doi:10.5539/mas.v13n3p112 \\ URL: https://doi.org/10.5539/mas.v13n3p112
}

\begin{abstract}
This study aimed at investigating kindergarten teachers' practices and beliefs relating to authentic assessment. The study also aimed at investigating differences in teachers' practices and beliefs based on level of education, study major, and length of experience. The sample of the study consisted of (92) teachers working in kindergartens in the suburbs of Jerusalem. Two questionnaires were developed and implemented to collect the data of the study. In addition, individual semi-structured interviews were conducted with 20 teachers from the sample of the study. Content analysis of some kindergarten documents was also used. The results showed that worksheets were the main method used to assess children learning, while project-based assessment was not used at all. In addition, the results showed significant differences in the teachers' utilization of authentic assessment methods relating to level of education and study major, but there were no differences relating to the length of the teachers teaching experience. The teachers showed a strong belief in the importance of authentic assessment methods. The results of the interviews and content analysis supported the findings of the questionnaires. The study concluded a number of recommendations for future research, teacher educators and kindergarten principals.
\end{abstract}

Keywords: authentic assessment, kindergarten teachers, practices and beliefs 


\section{Introduction}

Childhood is an important developmental stage which had its own defining characteristics. It is considered the most critical developmental stage as it plays a significant role in the formation of a person's personality and future learning. Interest in childhood and children has grown with the development and prosperity of communities and the advancement of science. Researchers have been paying special attention to the critical role of the early years of a child's life and how they affect the development of a child's thinking and the formation of his personality and determine the future course of his life (Bredekamp \& Copple, 1997).

Childhood programs are concerned with providing the best services to children. This is achieved when the people who are concerned with kindergarten teachers' education are aware of the importance of setting appropriate goals for their programs, and can select experiences that satisfy children's needs for learning and development in accordance with the standards of early childhood development and learning, and can evaluate children's development and the programs presented to them (Kwon, 2002). For this, it was necessary to investigate the process of assessing children and to look critically at the types, methods and functions of assessment used with children.

Assessment is a systematic process intended to provide information and descriptive evidence based on which judgments and decisions can be made with regard to children's programs and what is provided to them. Assessment reveals the success of programs and the effectiveness of the activities used therein. The assessment process is not an end in itself to identify children with certain characteristics, but it is part of the learning process that guides, promotes, and corrects their course (Snyder et al., 2008).

Assessment is an intentional, structured process that aims at collecting information about the educational process and interpreting evidence on which judgments about children, teachers, programs, or educational institutions are made. It is the process of determining the extent to which goals have been achieved, or determining the level of the child's achievement of certain results and experiences. Assessment is an important element in the teaching/learning process; it is the starting point for subsequent learning experiences and is the starting point for curriculum development and later modification (Al-Absi, 2010; Muhiedat and Al-Mahasnah, 2009).

In childhood, assessment is of great importance. It helps to diagnose children's strengths and weaknesses, and to identify all aspects of their development and also helps to build relationships with adults. In addition, assessment aids kindergarten teachers to review their goals and to match them with activities and assessment means they use (Leitschuh, Harring, \& Dunn, 2014; Hills, 1999).

McConnell and McEvoy (2002) and Kwon (2002) criticize the use of inappropriate assessment tools for children, because, in their view, assessment is appropriate for science, mathematics, language and writing, but is irrelevant for developmental, emotional, social, ethical, and sensory motor domains. Therefore, assessment should be considered in a holistic manner that involves all aspects of development and all the experiences that children face in their life contexts.

Consequently, people involved in the education of children (e.g. kindergarten teachers) should seek an assessment process that allows them to understand children's abilities, development in general, and development during specific periods of time. Assessment also contributes to the development of the curriculum and to improving its quality and making it more individualized in case this is sought. The identification of the strengths and weaknesses of a group of children will make the teacher more aware at the stage of planning activities to choose what suits each child according to his abilities. In addition, it helps to identify the difficulties faced by some children in various fields, and hence helps the teacher to plan specific tasks for specific children (Issa, 2004).

In order for teachers to make a comprehensive and holistic assessment of children, they should utilize authentic assessment. Authentic assessment is also known as realistic assessment, original assessment, performance-based evaluation, and alternative evaluation. Regardless of the term used, authentic assessment is based on the concept that evaluation is an integrative process that takes into account all areas of cognitive, linguistic, physical, social, emotional and moral development.

Authentic assessment reflects the child's real achievements and measures them in real situations. It involves children in tasks of value and meaning to them and which seem to be learning activities rather than part of an assessment process. Children practice higher thinking skills and can solve real life problems and soon acquire the ability to make correct judgments. Authentic assessment focuses on all aspects of a child's development, rather than relying on fixed grades, as in traditional assessment, which does not give enough information about learning outcomes, restricts them to few narrow contexts, and ignores the child's development (Al-Bashir and Barham, 2012). 
In this regard, authentic assessment is a methodology adopted by kindergartens for monitoring the development and learning of children, and a set of real evaluation methods that relate to the child's world and his/her surroundings. Educators and practitioners in early childhood (i.e. kindergarten stage) conduct authentic assessment in order to collect real data which shows children's interests, strengths and weaknesses and then use this information in partnership with teachers and parents to create an environment conducive to learning. Authentic assessment also seeks to develop the capacities of children since evaluation goes hand in hand with their care and attention (Zollitsch, \& Dean, 2010; Isa, 2004; Dichtelmiller \& Ensler, 2004).

Authentic assessment is concerned with the development of children's higher mental processes such as discovery, inquiry and problem-solving, In other words, assessment requires children to engage in tasks and activities that require them to think, problem-solve and apply what they have learned in life contexts. Authentic assessment is structured so that it takes into account the individual differences between children in their abilities and learning patterns by providing assessment activities that determine the achievement of each child individually. Authentic assessment also encourages children to engage in learning and working together (Bagnato et al. 2014).

Authentic assessment is characterized by a number of features that distinguish it from assessment which is primarily based on worksheets and tests. In authentic assessment children are given specific tasks related to their life contexts and learning, thus allowing the comparison of the development of each child individually and monitoring the process of his/her development. Recognizing individual differences among children allows feedback to be addressed to specific individuals, which can contribute to their development in all areas of growth (Bagnato et al., 2014).

In assessing children, a number of tools are used to measure their development and learning including most importantly: observation, the portfolio, and the narrative. Observation is one of the most important means that enable the teacher to understand the nature of the growth and development of her children and to plan programs and provide ways to meet their developmental needs and match their abilities and level of maturity (Al-Nashef, 2004). It is one of the tools of authentic assessment. In order for its objectives to be achieved, the kindergarten teacher should have enough information about how observation works. Observation, which is both an art and a science, requires skills that the teacher must be trained on and must practice. The teacher must also understand the nature of children's development and needs so that they can target those aspects that should be observed and can interpret children's practices according to their developmental stage (Moreno, Klute, 2011).

The portfolio is one of the methods of real-time assessment used to document children's work. It provides a clear picture about the development of children that allows concerned people to make decisions regarding the development of the programs offered to them during their stay in the kindergarten. The child's kindergarten portfolio includes a conscious selection of children's work, such as works of art, samples of collected materials, drawings and pictures, teacher's notes, parents' notes, and narrative records (storybook) (Al-Sumairi, 2004).

The narrative is a short story that has a beginning and an end. It takes up to 15 minutes at the most and is between 7-8 sentences about the child's behavior, language and communication and interaction with others. The writing may be followed by a chart showing the child's growth and other behaviors that show his development and learning (Brewer, 2005).

Mahaadat and Al-Mahasneh (2009), Al-Absi (2010) and Issa (2004) show the importance of assessment using lists of verbal evaluation made by observing the child in various activities. In this case, assessment means that the teacher is both an observer and a participant. She collects information about children and records them in order to utilize them in the verbal evaluation. Based on this perspective, evaluation depends on the use of different strategies for collecting information. The teacher can develop a narrative based on what she has written while observing the child work, play and interact with others.

Based on the above, authentic assessment is a means for developing child learning as a whole. Therefore, a number of studies have been conducted on authentic assessment in early childhood and at other educational stages. Bagnato et al. (2014) criticized the use of early childhood assessment techniques based on tests and conducted a survey in 22 US states involving 969 people working in the field of childhood in order to find an alternative. The results highlighted the importance of applying authentic assessment tools in kindergarten classes and the need to look for ways to apply them in a more effective manner.

Zu'bi (2013) investigated the degree of knowledge and practice of authentic assessment strategies of 92 tenth grade mathematics teachers in Jordan. The study also aimed at identifying the impact of gender, education and length of experience on the degree of knowledge and practice of these strategies. The results showed a much lower degree of use of authentic assessment tools than expected. Gender, education and experience were found to have no impact on the use of authentic tools, though gender and education were found to correlate with the teachers' beliefs about 
authentic assessment tools and strategies. The results also showed that the most limiting reasons for the low use of authentic assessment methods from the teachers' point of view included that fact that it is time consuming and requires a lot of effort on top of their high teaching load and the difficulty of the curriculum.

Moreno \& Klute (2011) study aimed at measuring the importance of employing authentic assessment tools in kindergarten, their validity and reliability, and the feasibility of using them by teachers and caregivers of children enrolled in the Head Start program. The study, which was conducted on a sample of (123) children, (23) teachers and child care providers, used a semi-experimental design. The teachers and caregivers were trained to employ authentic assessment tools with the children. Observation was used as a measure of the children's various areas of development: cognitive, social, emotional and readiness for reading. The results showed the importance of employing authentic assessment tools in evaluating the performance of children in kindergarten and prekindergarten to plan meaningful learning programs for children which contribute to their development in light of the limitations of the use of authentic assessment tools with young children.

Abu Awad and Abu Sinina (2011) aimed to investigate the beliefs of social studies teachers in UNRWA's (The United Nations Relief and Works Agency for Palestine Refugees) basic schools about alternative evaluation and its correlation with certain variables. The study was conducted on 84 teachers of social studies at UNRWA schools. The results showed that social studies teachers have positive and supportive beliefs about the benefits of alternative assessment, its nature and teacher practices of it. The results also indicated that there were no differences in the teachers' beliefs towards alternative assessment due to gender, while there were differences of statistical significance in the beliefs of teachers attributed to teacher's education, study major and years of experience.

Al-Shara'a (2011) investigated the extent to which Islamic Education teachers employ authentic assessment strategies and tools from the point of view of school headmasters and the impact of gender, experience, and education on that. The results of the study showed that according to the headmasters, the extent of the employment of Islamic Education teachers of the authentic evaluation strategies and tools was high. The study also revealed that there were no statistically significant differences in the degree of employment of Islamic Education teachers for authentic evaluation strategies due to gender, or length of teaching experience.

Murad (2001) conducted a study to identify the evaluation methods used by the teachers of the first cycle in primary education in Bahrain. The results showed that the teachers utilize all kinds of tests as well as observation to an acceptable extent. However, there was a clear underuse of student portfolios as an acceptable method of authentic assessment method.

Al-Sumairi's study (2004) aimed at developing a general framework for building an electronic file for use as a tool for evaluating the performance of kindergarten children. The results of the study showed that the child's electronic file was used extensively as an assessment tool. It appeared that the electronic child file is an effective tool for achieving the three purposes of the documentary file: compiling the learner's experiences and achievements, selecting the best child's works and justifying that choice, revealing the development of the child's development and progress of learning.

Al-Batsh (1998) conducted a study to develop a tool for assessing the performance of kindergarten children and which can serve as a tool to uncover behaviors that represent problems which should be cared for and to organize information about the child's cognitive, social and physical domains. The results of the study indicated that the suggested measure had validity and reliability as it was able to distinguish between the performance of ordinary and mentally disabled children.

It is hoped that the current study will provide a good picture about the practices and beliefs of kindergarten teachers in the suburbs of Jerusalem and will provide further insights about adopting the use of authentic assessment methods as a standard procedure at kindergartens.

\subsection{Problem of the Study}

The kindergarten period is a special stage in the life of children in all educational institutions in the world, which adopt a comprehensive holistic approach to child growth and development, and which seek to develop children in an integrated manner in all aspects: linguistic, physical, cognitive, social and emotional. This vision requires the best ways to ensure better learning and providing a platform, programs and activities that will accompany and support the developmental stages of children.

For kindergartens to ensure that their outcomes are in line with the goals and plans, principals and teachers should ensure that they assess their children in a variety of methods as they see fit. However, the process of evaluating children is not easy and needs to be informed and insightful, and requires hard work to understand what it is, and to choose the appropriate assessment strategies that suit the children's characteristics but at the same time that 
match the goals of children's education at that particular stage. This situation requires an investigation of the assessment strategies used in kindergartens from a developmental and educational perspective.

\subsection{Significance of the Study}

The present study draws its theoretical importance from studying the strategies of evaluating children, their learning and development, and what should be known about the importance and functions and types of assessment, and training teachers to employ it effectively.

Hence, there is a clear need to conduct studies on children's assessment in a holistic manner; in other words, in a manner which considers assessment as a way to help children develop and in the meantime develop the services provided to them. This study aims to propose a realistic view of assessment, and hopefully will be a welcome contribution to the literature on childhood education.

In addition, this study seeks to highlight the importance of assessment as an integral part of the entire educational process. This means that kindergartens can benefit from this study by becoming familiar with the relevant assessment strategies and how to use them effectively.

\subsection{Study Questions and Objectives}

This study aimed to investigate the practices and beliefs of authentic assessment of kindergarten teachers working in the suburbs of Jerusalem. Specifically, the study aimed to answer the following questions:

Question 1: What is the mean for the practice of authentic assessment methods of kindergarten teachers in the suburbs of Jerusalem?

Question 2: Do the means of practice of authentic assessment methods of kindergarten teachers in the suburbs of Jerusalem vary according to the teacher's qualification?

Question 3: Do the means of practice of authentic assessment methods of kindergarten teachers in the suburbs of Jerusalem vary according to the teacher's study major?

Question 4: Do the means of practice of authentic assessment methods of kindergarten teachers in the suburbs of Jerusalem vary according to the teacher's years of experience?

Question 5: What is the mean for the beliefs of kindergarten teachers in the suburbs of Jerusalem towards authentic assessment methods?

Question 6: Do the means for the beliefs about authentic assessment methods of kindergarten teachers in the suburbs of Jerusalem vary according to the teacher's qualification?

Question 7: Do the means for the beliefs about authentic assessment methods of kindergarten teachers in the suburbs of Jerusalem vary according to the teacher's study major?

Question 8: Do the means for the beliefs about authentic assessment methods of kindergarten teachers in the suburbs of Jerusalem vary according to the teacher's years of experience?

\section{Method}

\subsection{Study Design}

A descriptive analytical approach was used in this study, and it aimed at revealing the level of practice and beliefs towards authentic assessment methods of kindergarten teachers in the suburbs of Jerusalem.

\subsection{Study Population}

The study population consisted of all 120 kindergarten teachers in the suburbs of Jerusalem, according to the official records of the Directorate of Education 2015-2016 .

\subsection{The Study Sample}

The questionnaire was distributed to all members of the study population (120 teachers). Ninety-two responses were returned (83\%), which is an acceptable percentage. Table (1) shows the distribution of the sample of the study according to qualification, study major and years of experience.

Table (1) Distribution of participants according to qualification, study major, and years of experience

\begin{tabular}{|c|c|c|}
\hline Variable & Category & Duplicate (Percentage) \\
\hline (Academic) qualification & Tawjihi (Secondary school) & $18(20 \%)$ \\
\hline
\end{tabular}




\begin{tabular}{|c|c|c|}
\hline \multirow{4}{*}{ Study major } & Teaching diploma & $32(35 \%)$ \\
\cline { 2 - 3 } & Bachelor & $42(45 \%)$ \\
\cline { 2 - 3 } & None & $18(19 \%)$ \\
\cline { 2 - 3 } & $\begin{array}{c}\text { Science and Mathematics } \\
\text { Social, Islamic Education }\end{array}$ & $9(10 \%)$ \\
\cline { 2 - 3 } & Kindergarten & $28(30 \%)$ \\
\cline { 2 - 3 } & Primary Education & $21(23 \%)$ \\
\hline \multirow{3}{*}{ Years of Experience } & Less than 5 Years & $33(18 \%)$ \\
\cline { 2 - 3 } & 5-10 years & $36(39 \%)$ \\
\cline { 2 - 3 } & More than 10 years & $23(25 \%)$ \\
\cline { 2 - 3 } & & \\
\hline
\end{tabular}

\subsection{Study Tools}

The first tool: Measuring the level of practice of kindergarten teachers of authentic assessment.

A questionnaire was developed to measure the practice of kindergarten teachers of authentic assessment and it consisted of two parts. The first part sought to collect background information about the teachers. The second part consisted of (12) items measuring the level of practice of the teachers of the authentic assessment methods. The following three-dimensional Likert scale was used: (3) Always, (2) Rarely, (1) Never.

Validity and reliability of the questionnaire

In order to ascertain the validity of the questionnaire, it was verified by five education professors who hold a doctorate in childhood education, curricula or teaching methods. The questionnaire was modified according to the comments and suggestions of the referees. The reliability of the questionnaire was tested using (Cronbach Alpha), with a value of 0.82 . This is considered a high degree of consistency.

The second tool: Identifying the teachers' beliefs towards authentic assessment

A questionnaire was designed to measure the beliefs of kindergarten teachers in the suburbs of Jerusalem towards authentic assessment. It consisted of two parts: The first part sought to collect background data about the teachers. The second included items examining the teachers' beliefs about authentic assessment and consisted of (25) items, rated according to the following five-point Likert scale: (5) Strongly Agree, (4) Agree, (3) Disagree, (5) Strongly Disagree.

Validity and reliability of the second tool

To ascertain the validity of the second questionnaire, the questionnaire was refereed by five education professors who hold a doctorate in childhood, curricula and teaching methods. The questionnaire was modified according to the referees' comments and suggestions. The reliability of the second tool was tested using (Cronbach Alpha), with a reliability value of 0.87 , which indicates a high degree of reliability.

The third tool: Analysis of the assessment documents used in kindergartens

The assessment documents used in 10 kindergartens were analyzed. These documents included children's files, worksheets and records. The following points were noted:

- The goal of analysis: identify the practices of kindergarten teachers in the suburbs of Jerusalem regarding the methods of authentic assessment.

- Unit of analysis: Use the word and the sentence.

- Comprehensiveness of analysis: The analysis should include the content of all of the assessment files, worksheets and records.

Reliability of document content analysis

In order to detect the consistency of data analysis, the researchers utilized the following:

Intrapersonal reliability over time (within personal): The analysis was done twice 20 days apart. A holistic equation was used to calculate the coefficient of stability during the calculation of the intra personal. $2 \mathrm{M}(\mathrm{N} 1+\mathrm{N} 2)$ 
$\mathrm{N} 2$ : The number of categories analyzed the second time.

N1: The number of categories analyzed the first time.

2M: The number of categories agreed upon in the first and second time.

The intrapersonal coefficient was $85 \%$, indicating an acceptable result.

The fourth tool: Interview with teachers

The interview is an important tool that allows individuals the opportunity to express their thoughts, perceptions, attitudes, and selves by using their own vocabulary, and expressions that reveal their inner selves. In this study, the researchers conducted an individual, semi-structured interview with 20 of the sample kindergarten teachers. The interviews, which included six questions, were used to verify the data collected from the teachers' practices on real assessment methods via the questionnaire. The interviewees were each asked about the tools they use in child assessment, the developmental aspects that she focuses on, the assessment tools and sources she utilizes, the documentation of the assessment and evaluation processes and how she makes use of the results of the assessment.

The interview questions were piloted with teachers outside the study sample. Some of the questions were changed, reformulated or dropped based on the results of the pilot interviews. )

\section{Results and Discussion}

\subsection{Results of the First Study Question}

What is the mean for the practice of authentic assessment methods of kindergarten teachers in the suburbs of Jerusalem?

To answer this question, the means and standard deviations of the sample responses were calculated to estimate the level of practice of kindergarten teachers in the Jerusalem suburbs of authentic assessment methods with a mean of 2.54 and a standard deviation of 0.42 as shown in Table 2.

Table (2) Means and standard deviations for the authentic assessment methods practiced by the study sample

\begin{tabular}{|l|c|c|}
\hline \multicolumn{1}{|c|}{ Item } & Mean & SD \\
\hline Worksheets & 2.77 & 0.44 \\
\hline Structured observation & 2.20 & 0.70 \\
\hline Rating scales & 2.11 & 0.70 \\
\hline Narrative record & 1.93 & 0.67 \\
\hline Group work & 2.07 & 0.53 \\
\hline Self evaluation & 2.04 & 0.64 \\
\hline Simulation and role play & 2.03 & 0.54 \\
\hline Student portfolio & 1.98 & 0.73 \\
\hline Checklists & 1.88 & 0.64 \\
\hline Peer evaluation & 1.91 & 0.52 \\
\hline Description of the learning process & 1.84 & 0.62 \\
\hline Projects & 1.5 & 0.54 \\
\hline
\end{tabular}

Table 2 shows that assessment based on worksheets scored the highest mean (2.77), followed by assessment based on structured observation (2.20), assessment lists (2.11) and group work (2.07). Self-assessment (2.04) was followed by simulation and role-playing (2.03), student-portfolios (1.98), and narrative records (1.93) and peer evaluation (1.91), and learning process description records (1.84). Assessment based on projects achieved the lowest mean (1.5).

The relatively high dependence on worksheets as an assessment tool can be attributed to the learning outcomes and the development aspects targeted by the kindergarten. The kindergartens in which the study was conducted focus largely on the cognitive and linguistic domains (pre-reading and writing skills in particular). This can also be explained by the large number of children in kindergarten classes, which makes the teacher's task of using other methods more demanding in terms of time and effort.

The results of the interviews with the teachers support this interpretation as they stated that the work papers are 
imposed on them by the kindergarten administration. This focus on the use of working papers is most probably due the pressure of the parents, who wish to have some tangible evidence of their children's learning.

\subsection{Results of the Second Study Question}

Do the means of practice of authentic assessment methods of kindergarten teachers in the suburbs of Jerusalem vary according to teacher's qualification?

To answer this question, one way ANOVA was used; the results appear in Table 3

Table 3. Results of ANOVA for the difference between means for the choice of method of assessment according to teacher's qualification

\begin{tabular}{|c|c|c|c|c|c|c|c|c|c|}
\hline $\begin{array}{l}\text { Source } \\
\text { variance }\end{array}$ & of & $\begin{array}{l}\text { Total } \\
\text { squares?? }\end{array}$ & of & $\begin{array}{l}\text { Degree } \\
\text { freedom }\end{array}$ & of & $\begin{array}{l}\text { Mean } \\
\text { squares }\end{array}$ & of & $\begin{array}{l}\text { F } \\
\text { Value }\end{array}$ & $\begin{array}{l}\text { Level } \\
\text { significance }\end{array}$ \\
\hline Inter group & & 6.754 & & 2 & & 3.377 & & 31.313 & 0.001 \\
\hline Intra group & & 9.598 & & 89 & & 0.108 & & & \\
\hline Total & & 16.352 & & 91 & & & & & \\
\hline
\end{tabular}

Table 3 shows that the level of calculated significance 0.001 , which is less than $\geq 0.005$. So we reject the zero hypothesis (null hypothesis) and accept the alternative hypothesis. To examine differences between means according to teachers' qualification, a post hoc test was conducted as shown in Table 4.

Table 4. Results of Scheffe' Test for the qualification variable

\begin{tabular}{cccc}
\hline & Tawjihi & Diploma & BA \\
\hline Tawjihi & - & -0.61 & -0.71 \\
Diploma & +0.61 & - & -0.10 \\
BA & +0.71 & +0.10 & - \\
\hline
\end{tabular}

Table 4 shows that the difference between Tawjihi and the diploma is for the diploma and between the diploma and the BA is for the BA. This result is in agreement with Abu Awwad \& Abu Sneineh (2011) and is in disagreement with Al-Shir'ah (2011).

\subsection{Results of the Third Study Question}

Do the means of kindergarten teachers' practice of authentic assessment methods in Jerusalem suburbs vary according to teacher's study major?

To answer the question, the means and standard deviations for the responses of the study sample regarding kindergarten teachers' practice according to their study major were calculated as shown in Table (5).

Table 5. Means and standard deviations for the responses of the study sample according to teacher's study major

\begin{tabular}{lllll}
\hline Variable & Level & Number & Mean & Standard Deviation \\
\hline \multirow{4}{*}{ Study major } & None & 18 & 2.00 & 0.28 \\
& Science \& Math & 9 & 2.31 & 0.38 \\
& Arabic, English, Social Studies, Islamic Studies & 28 & 2.60 & 0.24 \\
& Kindergarten Education & 21 & 2.77 & 0.29 \\
& Primary Education & 16 & 2.88 & 0.34 \\
\hline
\end{tabular}

Table 5 shows that the highest mean for the responses of the sample regarding the teachers' practices of authentic assessment was 2.88 with a standard deviation of 0.34 for teachers with a degree in primary education. The lowest mean was 2.00 and the standard deviation 0.28 for teachers with no college degree.

In order to determine the level of practice level of kindergarten teachers in the suburbs of Jerusalem regarding methods of assessment according to study major, one way ANOVA was used as shown in Table (6). 
Table 6. Results of the ANOVA test regarding teachers' practice of authentic assessment methods according to study major

\begin{tabular}{lccccc}
\hline \multicolumn{1}{c}{ Source of variance } & $\begin{array}{c}\text { Total of } \\
\text { squares?? }\end{array}$ & Rank & $\begin{array}{c}\text { Mean of } \\
\text { squares }\end{array}$ & $\begin{array}{c}\text { Value of } \\
\text { f?? }\end{array}$ & $\begin{array}{c}\text { Level of } \\
\text { significance }\end{array}$ \\
\hline Inter group & 8.766 & 4 & 2.192 & 25.135 & 0.001 \\
Intra group & 7.586 & 87 & 0.087 & & \\
Total & 16.352 & 91 & & & \\
\hline
\end{tabular}

Table 6 shows that the calculated significance level of 0.001 was lower than the significance level $\geq \alpha(\mathbf{0 , 0 5})$ So the null (zero) hypothesis was rejected and the alternative hypothesis was accepted. To examine differences between means according to the teacher's study major, a post hoc test was conducted as shown in Table 7.

Table 7. Results of Scheffe' Test for the teachers' study major variable

\begin{tabular}{|c|c|c|c|c|c|}
\hline & None & $\begin{array}{r}\text { Math \& } \\
\text { Science }\end{array}$ & $\begin{array}{l}\text { Arabic, English, } \\
\text { Islamic Studies, } \\
\text { Social studies }\end{array}$ & $\begin{array}{r}\text { Primary } \\
\text { Education }\end{array}$ & Kindergartens \\
\hline None & - & -0.31 & -0.59 & -0.77 & -0.87 \\
\hline Math \& science & +0.31 & - & -0.28 & -0.46 & -0.56 \\
\hline $\begin{array}{l}\text { Arabic, English, } \\
\text { Islamic Studies, Social } \\
\text { studies }\end{array}$ & +0.590 & +0.28 & - & -0.17 & -0.27 \\
\hline Primary Education & +0.77 & +0.46 & +0.17 & - & -0.10 \\
\hline Kindergartens & +087 & +0.56 & +0.27 & +0.10 & - \\
\hline
\end{tabular}

Table 7 shows that after comparing the level of teachers' without study major practice with science and mathematics teachers shows a differences in favor of science and mathematics; when compared with teachers who have no study major with teachers of languages, social studies and Islamic education, the difference is in favor of the latter. Comparing teachers with no specialty with kindergarten teachers, there is a difference in favor of kindergarten teachers. Comparison of science and mathematics teachers with teachers of primary education showed differences in favor of primary education. The results show that the means of teachers who do not hold a bachelor's degree were the lowest among the other majors.

\subsection{Results of the Fourth Study Question}

Do the means of practice of authentic assessment methods of kindergarten teachers in the suburbs of Jerusalem vary according to teacher's years of experience?

To answer the fourth question, the means and standard deviations were calculated for the responses of the sample regarding the kindergarten teachers' practice according to the years of experience as seen in Table 8 .

Table 8. Means and standard deviations for the responses of the sample regarding the teachers' practices according to the years of experience

\begin{tabular}{lllll}
\hline Variable & Level & Number & Mean & Standard Deviation \\
\hline \multirow{3}{*}{ Years of experience } & Less than 5 years & 33 & 2.50 & 0.47 \\
& 5-10 years & 36 & 2.55 & 0.35 \\
& More than 10 years & 23 & 2.59 & 0.46 \\
\hline
\end{tabular}

In order to determine the level of practice of kindergarten teachers in the suburbs of Jerusalem for authentic assessment methods according to the years of experience, one way ANOVA was used as shown in Table 9.

Table 9. Results of the ANOVA test to determine the differences between the means for the responses of the sample 
kindergarten teachers regarding their practices of authentic assessment methods according to the years of experience.

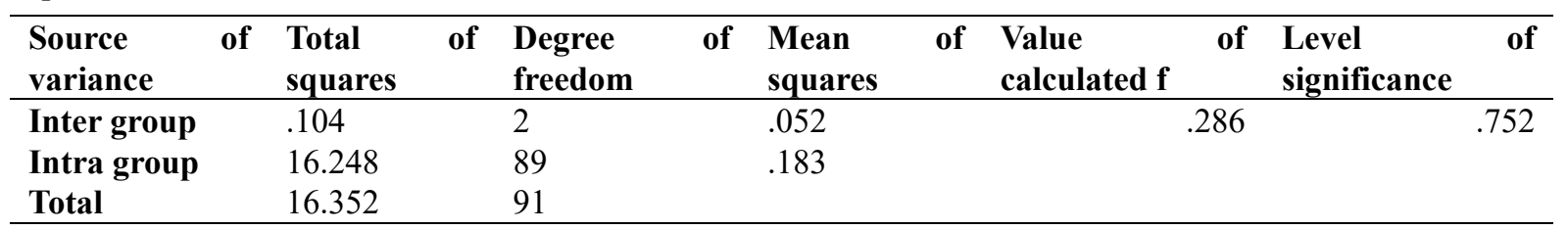

Table (9) shows that the significance level of 0.752 is greater than the significance ( $\alpha \alpha 0.05)$ and therefore we accept the 9 (null) zero hypothesis that there are no differences due to the years of experience. This result may be due to 2 possible reasons. The first is that teachers are subjected to pressure from the administration on learning methods and evaluation, and they are subject to traditional methods. The second is that the ability to use real assessment methods requires special training, and cannot be achieved with experience and time only.

\subsection{Results of the Fifth Study Question}

What is the mean for the beliefs of kindergarten teachers in the suburbs of Jerusalem towards authentic assessment methods?

In order to answer the fifth question, the means and the standard deviations of the beliefs of kindergarten teachers in the suburbs of Jerusalem about authentic assessment methods were calculated. The results showed a mean of 3.86 and the standard deviation of 0.31 . Table (9) shows the means of the beliefs of kindergarten teachers in the suburbs of Jerusalem towards the use of authentic assessment methods.

Table 9. Means of beliefs of teachers about authentic assessment

\begin{tabular}{|c|c|c|c|}
\hline & $\begin{array}{l}\text { Standard } \\
\text { Deviation }\end{array}$ & Mean & Statement \\
\hline 1. & 0.88 & 3.06 & $\begin{array}{l}\text { I expect to face a lot of difficulty using methods of authentic assessment in the } \\
\text { kindergarten. }\end{array}$ \\
\hline 2. & 1.00 & 3.30 & It's very difficult for kindergarten teachers to use authentic assessment methods. \\
\hline 3. & 0.91 & 3.31 & $\begin{array}{l}\text { It's very difficult for kindergarten teachers to make use of the results of authentic } \\
\text { assessment. }\end{array}$ \\
\hline 4. & 0.76 & 3.47 & $\begin{array}{l}\text { The methods of authentic assessment concentrate on the portfolio, observation, } \\
\text { checklists, and rating scale more than worksheets. }\end{array}$ \\
\hline 5. & 0.84 & 3.49 & The methods of authentic assessment emphasize high order thinking processes \\
\hline 6. & 0.80 & 3.59 & $\begin{array}{l}\text { The teacher avoids using comparison among students when using methods of } \\
\text { authentic assessment }\end{array}$ \\
\hline 7. & 0.71 & 3.63 & $\begin{array}{l}\text { I can face the difficulties I encounter when using the methods of authentic } \\
\text { assessment. }\end{array}$ \\
\hline 8. & 0.73 & 3.73 & Methods of authentic assessment help children to develop positive attitudes. \\
\hline 9. & 0.73 & 3.75 & $\begin{array}{l}\text { The use of authentic assessment encourages the teacher to organize the } \\
\text { kindergarten environment. }\end{array}$ \\
\hline 10. & 0.76 & 3.84 & $\begin{array}{l}\text { Authentic assessment gives the teacher an overall picture of the performance of } \\
\text { children. }\end{array}$ \\
\hline 11. & 0.82 & 3.84 & Authentic assessment respects individual differences among children. \\
\hline 12. & 0.78 & 3.85 & Methods of authentic assessment enhance children's self respect. \\
\hline 13. & 0.73 & 3.94 & $\begin{array}{l}\text { The employment of methods of authentic assessment provides a comfortable } \\
\text { atmosphere for the children. }\end{array}$ \\
\hline 14. & 1.02 & 3.95 & The use of authentic assessment strategies requires extra efforts from the teacher. \\
\hline 15. & 0.74 & 4.02 & The methods of authentic assessment are suitable for small children. \\
\hline $\begin{array}{l}16 . \\
17 .\end{array}$ & 0.73 & 4.08 & $\begin{array}{l}\text { The use of the of authentic assessment methods encourages children to learn. } \\
\text { The use of the of authentic assessment methods encourages children's self- } \\
\text { evaluation. }\end{array}$ \\
\hline 18. & 0.57 & 4.15 & Authentic assessment emphasizes the various areas of children's development. \\
\hline 19. & 0.63 & 4.25 & $\begin{array}{l}\text { The use of the authentic assessment methods contributes to the work in } \\
\text { kindergartens. }\end{array}$ \\
\hline
\end{tabular}




\begin{tabular}{|c|c|c|c|}
\hline 20. & 0.78 & 4.28 & $\begin{array}{l}\text { The use of the authentic assessment methods encourages the teacher to look for } \\
\text { the most suitable assessment method for the children. }\end{array}$ \\
\hline 21. & 0.55 & 4.31 & Authentic assessment provides children with feedback on their work. \\
\hline 22 & 0.56 & 4.31 & $\begin{array}{l}\text { The use of the authentic assessment methods allows the teacher to change roles } \\
\text { from controller to facilitator of children learning. }\end{array}$ \\
\hline 23. & 0.48 & 4.31 & $\begin{array}{l}\text { The use of the authentic assessment methods encourages the teacher to review her } \\
\text { teaching practices. }\end{array}$ \\
\hline 24. & 0.56 & 4.33 & $\begin{array}{l}\text { The use of the authentic assessment methods enhances the teacher's skill of } \\
\text { observing children }\end{array}$ \\
\hline 25. & 0.58 & 4.36 & $\begin{array}{l}\text { The use of the authentic assessment methods enhances the teacher's interest in } \\
\text { the children in a holistic way. }\end{array}$ \\
\hline
\end{tabular}

Table (9) shows an increase in the mean of all the items dealing with the benefits of real assessment and its positive effects on the learning and development of children. On the other hand, the means of the items that deal with the difficulties of applying the authentic assessment and taking advantage of it was average (less than 3.66). The results also show that the item that received the highest mean was (25), which states: "The use of the authentic assessment methods enhances the teacher's interest in the children in a holistic way."

\subsection{Results of the Sixth Study Question}

Question 6: Do the means of teachers' beliefs about authentic assessment vary according to the teacher's qualification?

To answer this question, the means and standard deviations of the responses of the teachers in the study sample regarding their beliefs about authentic assessment according to qualification were calculated. This is shown in Table 10 .

Table 10. Results of the ANOVA test regarding the beliefs of teachers about authentic assessment according to teacher's qualification

\begin{tabular}{rrrrr}
\hline Variable & Qualification & Numberl & Mean & SD \\
\hline Qualification & Tawjihi & 18 & 3.71 & 0.27 \\
& Diploma & 32 & 3.88 & 0.34 \\
& BA & 42 & 3.90 & 0.28 \\
\hline
\end{tabular}

Table (10) shows that the highest mean of the teachers' beliefs towards authentic assessment according to teachers with a BA degree was 3.90 with a standard deviation of 0.28 , followed by diploma holders scoring a mean of 3.88 and a standard deviation of 0.34 then teachers with Tawjihi who scored the lowest mean of 3.71 and a standard deviation of 0.27 .

In order to answer the sixth study question and to identify the beliefs of kindergarten teachers in the suburbs of Jerusalem towards the use of authentic assessment methods according to their qualification, one way ANOVA was used; the results are shown in Table 11.

Table 11. Results of the ANOVA test to determine the differences between the means for the responses of the sample kindergarten teachers regarding their practices of authentic assessment methods according to qualification.

\begin{tabular}{rrrrrrrr}
\hline Source $\begin{array}{r}\text { of } \\
\text { variance }\end{array}$ & Total $\begin{array}{r}\text { of } \\
\text { squares }\end{array}$ & $\begin{array}{r}\text { Degree } \\
\text { freedom }\end{array}$ & $\begin{array}{r}\text { of } \\
\text { squares }\end{array}$ & $\begin{array}{r}\text { of } \\
\text { squalue } \\
\text { calculated f }\end{array}$ & $\begin{array}{r}\text { Level } \\
\text { significance }\end{array}$ \\
\hline Inter group & .510 & 2 & .255 & 2.685 & \\
Intra group & 8.445 & 89 & .095 & & \\
Total & 8.955 & 91 & & & \\
\hline
\end{tabular}

Table (11) shows that the significance level of 0.074 is greater than the ( $\alpha \alpha 0.05)$; therefore, we accept the zero hypothesis that there are no differences in the practice of authentic assessment methods due to teachers' qualification. This result demonstrates the need for teachers to train in the use of authentic assessment methods. It is observable that teachers from the various majors have shown valid beliefs about authentic assessment methods, but these beliefs have not turned into practices. It is well known that the cognitive component of a particular 
learning (an assessment method in this case) is one of the prerequisites for its use, but it is not a guarantee of actual use. Training in the skill or-practical side is not less important than acquiring the cognitive aspect.

\subsection{Results of the Seventh Study Question}

Question 7: Do the means of teachers' beliefs about authentic assessment methods vary according to the teacher's study major?

To answer this question, the means and standard deviations of the responses of the teachers in the study sample regarding their beliefs about authentic assessment according to study major were calculated. The results appear in Table 12 .

Table 12. Means and standard deviations of the responses of the teachers in the study sample regarding their beliefs about authentic assessment according to their major/ study major

\begin{tabular}{lllll}
\hline Variable & Level & Number & Mean & SD \\
\hline \multirow{3}{*}{ Study major } & None & 18 & 3.71 & 0.27 \\
& Math \& science & 9 & 3.91 & 0.35 \\
& Arabic, English, Social Studies, Islamic Education & 28 & 3.84 & 0.28 \\
& Kindergarten & 21 & 3.88 & 0.31 \\
& Primary Education & 16 & 4.00 & 0.33 \\
\hline
\end{tabular}

In order to answer the seventh study question and to identify the beliefs of kindergarten teachers in the suburbs of Jerusalem towards the use of authentic assessment methods according to their study major, one way ANOVA was used; the results are shown in Table 13.

Table 13. Results of the ANOVA test to determine the differences between the means of the beliefs of the sample kindergarten teachers regarding the use of authentic assessment methods according to study major

\begin{tabular}{cccccc}
\hline Source of variance & $\begin{array}{c}\text { Total of } \\
\text { squares }\end{array}$ & $\begin{array}{c}\text { Degree of } \\
\text { freedom }\end{array}$ & $\begin{array}{c}\text { Mean of } \\
\text { squares }\end{array}$ & $\begin{array}{c}\text { Calculated } \\
\text { value of f }\end{array}$ & $\begin{array}{c}\text { Level of } \\
\text { significance }\end{array}$ \\
\hline Inter group & .760 & 4 & .190 & 2.017 & .099 \\
& & & & & \\
Intra group & 8.195 & 87 & .094 & & \\
Total & 8.955 & 91 & & & \\
\hline
\end{tabular}

Table (13) shows that the significance level 0.99 is greater than the significance value of $(\alpha \alpha 0.05)$ and therefore we accept the zero hypothesis that there are no differences in the teachers' beliefs about the use of authentic assessment due to study major. This result shows the gap between the teachers' beliefs and practices. As noted earlier, there were significant differences between the means of the use of authentic assessment, while no significant differences were found in regard to beliefs. Teachers from all disciplines believe in the importance of real evaluation, but the degree to which these beliefs are reflected in their actual practice is different.

\subsection{Results of the Eighth Study Question}

Question 8: Do the means of teachers' beliefs about authentic assessment methods vary according to the teacher's years of experience?

To answer this question, the means and standard deviations of the responses of the teachers in the study sample regarding their beliefs about authentic assessment according to the length of experience were calculated. The results appear in Table 14.

Table 14. Means and standard deviations for the responses of the study sample regarding their beliefs according to the years of experience

\begin{tabular}{lllll}
\hline Variable & Level & Number & Mean & Standard Deviation \\
\hline Years of experience & Less than 5 years & 33 & 3.88 & 0.28 \\
& 5-10 years & 36 & 3.87 & 0.34 \\
& More than 10 years & 32 & 3.81 & 0.29 \\
\hline
\end{tabular}


Table (14) shows that the highest mean of the teachers' beliefs towards authentic assessment methods according to the length of experience was for teachers with less than five years of experience with a mean of 3.88 and a standard deviation of 0.28 , followed by teachers with 5-10 years of experience scoring a mean of 3.87 and a standard deviation of 0.34 , For teachers with more than 10 years of experience, the mean was 3.81 and the standard deviation was 0.29 .

In order to identify the level of practice of kindergarten teachers in the suburbs of Jerusalem for real evaluation methods according to years of experience, one way ANOVA was used and the results are shown in Table 15.

Table 15. Results of the ANOVA test for the differences between the means for the beliefs of the sample kindergarten teachers regarding the use of authentic assessment methods according to years of experience.

\begin{tabular}{rrrrrrrr}
\hline Source of variance & \multicolumn{1}{c}{ Total $\begin{array}{r}\text { of } \\
\text { squares }\end{array}$} & $\begin{array}{r}\text { Degree } \\
\text { freedom }\end{array}$ & $\begin{array}{r}\text { Mean } \\
\text { squares }\end{array}$ & $\begin{array}{r}\text { Calculated } \\
\text { value of f }\end{array}$ & $\begin{array}{r}\text { Level } \\
\text { significance }\end{array}$ \\
Inter group & .079 & 2 & .039 & 0.394 & 0.676 \\
Intra group & .8 .876 & 89 & 0.100 & & \\
Total & 8.955 & 91 & & & \\
\hline
\end{tabular}

Table (15) shows that the significance level was 0.99 , which is greater than the significance $(\alpha \alpha 0.05)$ and therefore we accept the zero hypothesis that there are no differences regarding teachers' beliefs due to years of experience. This finding shows that the number of years of experience is not a decisive factor in shaping the teachers' beliefs about authentic assessment.

\subsection{Results of Interviews}

The results of the analysis of the tools used by kindergarten teacher in children's assessment indicate that the most common assessment tool is the worksheet followed by the observation. Assessment of children through projects was completely absent. This is confirmed by the results of the questionnaire that the worksheet was the most common assessment tool employed in kindergartens followed by observation. However, only 5 teachers took notes during their observations. The other teachers used observation but did not take down any notes of these observations.

As for the areas of development that teachers emphasize in the process of evaluating kindergarten children, 15 teachers confirmed that they focus on all areas of development Assessment in the kindergarten aims to evaluate the children's development and growth in the various areas: cognitive, linguistic, social, physical, and emotional While three teachers emphasized the role of evaluation in monitoring children's cognitive development, the child's ability to learn, sensory-motor development, to the neglect of other areas of development. One teacher focused on the development of the cognitive and emotional aspects in the first place, while another teacher pointed to the importance of assessing the child's language abilities especially that one of her students suffered from certain language problems. The emphasis of the teachers on the importance of assessment during interviews is consistent with the results of their responses about their beliefs included in the questionnaire shown in Table 9 above. The question about the importance of authentic assessment in the child's comprehensive evaluation scored the highest mean.

As for sources of assessment and who selects the assessment tools (i.e. the teacher or kindergarten head or both) the results of the interview with the teachers showed that (11) thought that the responsibility of assessment in the first place first is part of the kindergarten teacher's job and she has to search for assessment tools that are appropriate for children even though they do not have the freedom to choose those assessment tools that they believe in. In fact, the kindergarten teacher uses the evaluation tools the principal chooses. For example, most kindergarten principals use the worksheet as an assessment tool as an alternative to the test and ask their teachers to mark the worksheet so that the parents can have something that reflects the achievement of their children. In some cases, a grade is put on the child's Arabic or math notebook for the parents to see. However, 4 teachers indicated that they select their assessment tools in consultation with the principal as well as other colleagues. Three teachers indicated that they use the Internet to find suitable assessment tools since the principal leaves them the freedom to choose their own assessment tools and encourages them to be very innovative about the selection of appropriate assessment tools.

The teachers were in agreement that the results of assessment are often used to review the kindergarten teaching 
plan and the activities that are offered to the children, and their suitability and diversity. One teacher pointed out that the results of children assessment are used in giving feedback to students, developing the quality of the work, and in getting to know the children's inclinations and interests.

Ten teachers said that kindergartens are not prepared for the use of authentic assessment methods because the primary focus at most kindergartens is to teach children to write, read, numbers, addition and subtraction. Four teachers expressed their desire to apply authentic assessment methods in kindergartens and said that applying these methods is quite possible and is not difficult.

In regard to the feasibility of employing authentic assessment methods, 19 teachers indicated that they had not participated in any workshops or discussions about authentic assessment and how it is used. Eighteen teachers suggested enrolling in courses or workshops on using authentic assessment in kindergartens, and to involve directors in these workshops in order to convince them of the importance of authentic assessment. Three teachers suggested holding workshops on authentic assessment in which actual and successful cases of the use of authentic assessment in kindergartens are presented and in which theory is completely avoided.

\subsection{Results of Document Analysis}

The analysis of documents for 10 kindergartens in the suburb of Jerusalem showed that the most frequently used tools by the teachers are the worksheets followed by the child's portfolio, where worksheets and forms of child works are placed, but it is devoid of the teacher notes except (4) kindergartens where the teachers put the paper in the child's file which has weekly notes about each child that includes a description of his or her work, activities, participation and interaction. Three teachers used the kindergarten-based evaluation form, which focuses on the evaluation of developmental aspects (cognitive, linguistic, physical, social, and emotional).

The analysis of the kindergarten documents allowed the identification of the status of project-based evaluation, rating scale, and peer evaluation as methods of authentic assessment. However, no documentation or evaluation tools were found to indicate the use of project-based evaluation. The lists of appreciation were found in (6) kindergarten. These lists take the form of a certificate that is sent to the parents and includes a four or five-point scale marking the various areas of child development. Each of the main development areas is further divided into several items. The main areas of development that are usually found on the rating scale include the following.

First: General aptitude: includes knowledge of the place of residence and age, naming body organs, knowing the days of the week, the seasons of the year, identifying the features of each season, and visual discrimination.

Second: Mental abilities: includes classification of words and images according to various criteria property, distinguishing patterns, and imitating them, the creation of a new pattern, and knowing and distinguishing and drawing geometric shapes and counting verbally.

Third: Imagination and creativity: includes construction and artistic production, using language to express imagination, and the child's interaction in the socio-dramatic play corner.

Fourth: Psychological and social development, including self-confidence, use of language to express needs, independence, playing, sharing, commitment and discipline.

Fifth: Harmony at work, finishing tasks, making use of time, and putting back things after completing a task.

Sixth: Control of large muscles, includes running, jumping, and hopping.

Seventh: Control of fine muscles includes the use of colors, pens, paint brush, and paste.

Eighth: Language development includes readiness for reading, auditory discrimination, readiness for writing such as direction of writing, imitation of word drawing, and advanced writing skills such as writing letters and words from memory.

Ninth: The second language (English) includes distinction of letters and words, reading and writing words, and daily conversation.

Tenth: Islamic Education-includes memorization of short suras (chapters from the Quran) and du'aa (supplication).

\section{Recommendations}

1. The results of the study showed that teachers who do not hold a university degree were low on the use of authentic assessment methods compared to teachers with a college degrees. Therefore, it is recommended that those teachers should strive to get a college degree.

2. It is recommended that priority of employment at kindergartens be given to those who have a bachelor's 
degree in kindergarten education (or early childhood education). The results of the study showed that the means of responses about authentic assessment methods were higher for teachers with a degree in kindergarten education than the means of teachers with other study majors.

3. It is recommended that some training programs should be directed at kindergarten heads and should focus on improving their attitudes towards authentic assessment methods and raising their awareness of its advantages. The study showed that kindergarten heads prevent their teachers from using methods of authentic assessment and push them to use traditional methods of evaluation and rely mainly on worksheets.

4. It is recommended that the development of programs for training kindergarten teachers should focus on the relationship between the nature of learning outcomes and development target and methods of learning and assessment appropriate for them. Also, it is necessary to help teachers understand the links between the learning methods used and the appropriate assessment methods.

5. The results of the interviews pointed to the need to train teachers how to use authentic assessment methods, and the mechanism of recording observation notes organized and documented in special records.

\section{References}

Abu Awad, F., \& Abu Sneneh, O. (2011). The beliefs of social studies teachers in the basic schools at UNRWA about alternative assessment. Journal of Al-Quds Open University for Research \& Studies (In Arabic), 24(1), 229-266.

Alabsy, M. (2010). Authentic evaluation in teaching, (In Arabic). Jordan, Dar Almasera.

Al-Basheer, A., \& Barham, E. (2012). Using Alternative Assessment Strategies in Assessing Students' Learning in Mathematics and Arabic in Jordan, Journal of Educational \& Psychological Sciences (In Arabic), 13(4), 241 270.

Albatsh, M. (1998). Develop to evaluate children performance in preschool, DIRASAT (In Arabic), 25 (2), $340-452$.

Alnashef, H. (2000). Teaching and learning strategies in Early childhood (In Arabic), Cairo. Dar Alfikr Alarabi.

Alsomairy, L. (2004). Using electronic portfolio to evaluate children performance in kindergarten. International Journal for Research in Education (IJRE) (In Arabic), 19(21), 109-147.

Alzogby, A. (2013). Knowledge and Utilization Degree of Authentic Assessment Strategies and Tools by Mathematics Teachers, IUG Journal of Educational and Psychology Sciences (In Arabic), 21(3), 165-197.

Ashra'a, M. (2011). The degree of teacher employment of Islamic education to authentic evaluation strategies from perspective of principals in Madaba, Mu'ta for Research and Studies Humanities and Social Sciences (In Arabic), 26(1), 291-307.

Bagnato, S., Goins, S., Frontczak, C., \& Neisworth, J. (2014) Authentic Assessment as "Best Practice” for Early Childhood Intervention: National Consumer Social Validity Research, Topics in Early Childhood Special Education, 34(2), 116-127.

Bredekamp, S., \& Copple, C. (1997). Developmentally appropriate practice in early childhood programs, Revised edition. Washington, DC: National Association for the Education of Young Children.

Brewer, J. A. (2005). Introduction to Early Childhood Education (In Arabic), Boston, Pearson Education. (Translators: Alzreqat \& Naser).

Dichtelmiller, M., \& Ensler, L. (2004). Infant - Toddler assessment on program's Experience, Young Children, 17. Retrieved from https://www.naeyc.org/files/yc/file/200401/dichtel.pdf

Eva, E. (2004). Introduction to Early childhood, Translation: Alshafey, A (In Arabic), Gaza, Palestine.

Hills, W. (1999). Critical Issue: Assessing Young Children's Progress Appropriately, North Carolina.

Kwon, Y. (2002). Changing Curriculum for Early Childhood Education in England, Early childhood Research and Practice, 2(2). Retrieved from http://ecrp.uiuc.edu/v4n2/kwon.html

Leitschuh, C., Harring, R., \& Dunn, W. (2014). A Monitoring Tool of Infant and Toddler Movement Skills, Journal of Early Intervention, 36(1), 18-36.

McConnell, S., \& McEvoy, M. (2002). "Growing” Measures for Monitoring Progress in Early Childhood Education: A Research and Development Process for Individual Growth and Development Indicators, Assessment for Effective Intervention, 27(4), 3-14.

Mhidat, A., \& Almahasneh, I. (2009). Authentic Evaluation, (In Arabic). Jordan, Dar Jareer. 
Morad, K., \& Shareef, A. (2001). Evaluation Methods for Teachers in Elementary Education under the Educational Evaluation System, Journal of Educational \& Psychological Sciences (In Arabic), 2(4), 191-193.

Moreno, A., \& Klute, M. (2011). Infant-toddler teachers can successfully employ authentic assessment: Learning through Relating system, Early Childhood Research Quarterly, 26, 484-496.

Snyder, W., \& Roach, T. (2008). Assessment in Early Childhood Instruction-Focused Strategies to Support Response-to-Intervention Frameworks, Assessment for Effective Intervention, 34(1), 25-34

Zollitsch, B., \& Dean, A. (2010). Authentic Assessment in Infant \& Toddler Care Settings: Review of Recent Research, Research \& Policy Brief. Retrived from http://digitalcommons.usm.maine.edu/cgi/viewcontent.cgi?article=1005\&context=cyf

\section{Copyrights}

Copyright for this article is retained by the author(s), with first publication rights granted to the journal.

This is an open-access article distributed under the terms and conditions of the Creative Commons Attribution license (http://creativecommons.org/licenses/by/4.0/). 